\title{
THE NEED FOR PRECISION FEED BUDGETING AS A FARMING TOOL
}

\author{
O. F. PARKER " \\ Ruakuru Agricultural Research Centre, Hamilton
}

Abstract

\begin{abstract}
Previously published data from Dairy Board surveys reveal de-' clining trends of dairy production, on both a per-cow and a unit area basis, over the past five years, and only a very small 'average increase over the past twenty years. Reasons are advanced for introducing a feed budget approach to farming. This approach has been extremely useful in intensive stocking trials with dairy cows at the Ruakura Nutrition Centre over the past seven years. Experimental evidence is used to demonstrate the feasibility and desirability of using practised eye appraisal to assess pasture dry matter cover and how, on farms stocked to maximize pasture use, this information can then be applied to meeting the changing needs of cattle throughout the year. Acceptance of this approach has led to improved feeding and productivity of livestock, increased total production, and greater economic returns from dairy farms.
\end{abstract}

\section{INTRODUCTION}

IN THE FIVE-YEAR PERIOD ending with the 1970-1 season, on New Zealand farms which were devoted solely to dairying, what appears to be a monument to incompetence has emerged. Both the area in pasture and herd size have increased by about $18 \%$, but milk-fat production both per cow and per hectare in pasture has decreased by about $15 \%$. The net result has been a mere $2.6 \%$ increase in production per farm in that time (Anon., 1971). Even conceding that that was a period of marked variability in seasonal conditions, it might well be argued that any small recent Increases in average dairy farm productivity are due almost entirely to the effects of amalgamation and acquisition leading to larger, less efficient farms.

These data could be taken as representing an indictment of present dairy farm practices, attitudes of farming leaders and dairy farmers, and indeed of the whole national approach to dairying in recent years.

During the past 20 years a great deal of attention has been given to improving sire selection programmes and to breeding cows with improved genetic potential for milk production. The widespread use of artificial breeding and the greatly expanded use of advisory and consultant services have produced an improvement of only about $1 \%$ per year in national dairy farm out- 
'put, and an average increase in per-cow production of only $0.65 \%$ per year, over the two decades (Anon., 1971).

What factors are primarily responsible for this near-stagnation? Are we at present unable to find answers to many important problems confronting farmers in their quest for higher and more profitable levels of production? Or is it due to a general state of inertia engendered by a complacency that encourages the retention of time-worn methods and thinking? Because data derived from research studies made available from the mid-19'60s onwards, if noted and applied, might have arrested and reversed the apparently declining trends in dairy production, it seems that a lack of interest and incentives rather than of information has been mainly responsible.

It is pertinent at this point to compare milk-fat productions in the two recent drought seasons of 1969-70, 1970-1 with the two seasons that immediately preceded them. (Data for industry cows from Anon., 1971.)

TABLE 1: MILK-FAT PRODUCTION (kg)*

\begin{tabular}{|c|c|c|c|c|c|c|c|c|}
\hline & \multicolumn{2}{|c|}{$1967-8$} & \multicolumn{2}{|c|}{$1968-9$} & \multicolumn{2}{|c|}{ 1969-70 } & \multicolumn{2}{|c|}{ 1970-1. } \\
\hline & $\begin{array}{l}\text { per } \\
\text { cow }\end{array}$ & $\begin{array}{c}\text { per } \\
\text { h a }\end{array}$ & $\begin{array}{l}\text { per } \\
\text { cow }\end{array}$ & $\begin{array}{r}\text { per } \\
\text { ha }\end{array}$ & $\begin{array}{l}\text { per } \\
\text { cow }\end{array}$ & $\begin{array}{c}\text { per } \\
\text { ha }\end{array}$ & $\begin{array}{l}\text { per } \\
\text { Cow }\end{array}$ & $\begin{array}{c}\text { per } \\
\text { ha }\end{array}$ \\
\hline Industry cows & 126 & & 129 & & 116 & & 119 & \\
\hline Ruakura twins $\dagger$ & 125 & 513 & 129 & 530 & 125 & 513 & 121 & 496 \\
\hline
\end{tabular}

*Per cow: "At the pail". Per hectare: per hectare in grass.

†"Late" calving only in 1969-70, 1970-1.

Table $1^{\text {' }}$ shows average industry milk-fat productions for the two drought years of $118 \mathrm{~kg} / \mathrm{cow}$ and $256 \mathrm{~kg} / \mathrm{ha}$, and $128 \mathrm{~kg} /$ cow and $267 / \mathrm{ha}$, for the two preceding ones. By contrast, Ruakura productions for cows run on a completely self-containedfor-feed-basis at $4.1 / \mathrm{ha}$ were, respectively, $123 \mathrm{~kg} / \mathrm{cow}(505 \mathrm{~kg} /$ ha) and $127 \mathrm{~kg} / \mathrm{cow}(522 \mathrm{~kg} / \mathrm{ha})$. It is seen that, in the case of the industry cows, two droughty years caused an average drop in production per cow of $8 \%$ and per-hectare yields dropped to an abysmal $256 \mathrm{~kg}$. This compares most unfavourably with the Ritakura figures which show a drought effect of $3 \%$, and per-acre yields, despite the droughts, of virtually double the industry ones., The data further show that in the two "normal" years preceding the droughts the Ruakura cows, in spite of being identical twins and stocked at almost twice the intensity of the industry cows 
calving at the same time, produced at a similar individual level to the latter, whilst in the drought seasons when calving 5 weeks later they averaged an additional $5 \mathrm{~kg}$ of milk-fat per cow and $249 \mathrm{~kg}$ per hectare. It is interesting to note here that another Ruakura herd, consisting of cows of very high genetic merit and run at stocking rates varying from 3.5 to 3.7 cows/ha but calving at the normal time, suffered a comparative drop. in production of $5 \%$ over the drought seasons (J. D. J. Scott, pers. comm.) .

It is surely not expected that identical twin cows, stocked at 4.1 /ha and calving either early or late, should produce at any higher level as individuals than the cows from which they were derived. What should be recognized is that, stocked as they are at a level to ensure the direct use by the cows of as much as possible of the grass grown, they ought to be more vulnerable to variations in weather and pasture growth patterns from year to year. Yet their performance in drought years was, superior to that of their fellows in the industry at large.

Growth information from Ruakura pastures that are generally regarded as only average indicates that on dairy farms with improved pastures in the Waikato, annual pasture production varies between 15000 and $17000 \mathrm{~kg}$ of dry matter (DM) per hectare, depending on whether the season is respectively poor or good (Hutton, Bryant and Parker, unpublished). As an average Jersey cross dairy cow requires only $3400 \mathrm{~kg}$ DM a year to produce $160 \mathrm{~kg}$ of milk-fat (Hutton, 1966; Joyce and McLean, 1970), obviously the average stocking rate of only slightly more than 2.5 cow equivalents per hectare (Anon., 1971) is quite inadequate, being sufficient to account for little more than one half of the grass grown. This wastage is a consequence of the low stocking rates relative to other inputs, in particular levels of fertilizer applied. Recent dairy farm surveys (Anon;, 1971) indicate that, on average, about $\$ 1000$ per year is spent on fertilizers and seeds. However, the question may well be asked: Why grow more grass when only about two-thirds of the amount which can be grown without any more than maintenance topdressing will be needed anyway?

To make effective use of more of this surplus feed, a substantial increase in carrying capacity is required; but increasing stock numbers will prove insufficient on its own - associated changes in feeding and management practices are equally important. Especially significant amongst these are time of calving and of drying-off relative to the onset of spring and winter, respectively. For the average farmer committed by tradition to 
July-August calving, and faced consistently with the problem of feeding his herd adequately during late pregnancy and early lactation through June, July and August, the prospect of compounding his difficulties by increasing cow numbers is scarcely encouraging.

However, there is a way to make necessary changes which is available to every farmer at no extra cost, and with the possible added dividends of higher production per cow and per hectare, greater profit, more leisure time, and less worry. This has been described in published reports (Hutton, 1962, 1963, 1966a, b, 1968), at farmers field days (Hutton, 1971), farmer and advisory officer seminars and farm visits, during the past decade. On some commercial farms and demonstration units, these recommendations have been followed, and increased production and profits have resulted.

Particular attention has been given to pasture management and feeding of the herd over the autumn-winter period. Fifteen years ago, Wallace (1958) showed, for seasonal dairying conditions in South Auckland, the merit of taking pastures progressively out of grazing by the milking herd from about mid-April onwards and retaining these as a winter reserve. During the following 6 to 8 weeks until drying off, each cow receives about $220 \mathrm{~kg}$ DM as hay or silage together with an equivalent amount of pasture $\mathrm{DM}$, and this maintains milk production at a level similar to that obtained from grass alone. Pastures grazed in conjunction with supplementary feeding in this way from mid-April have a total cover of about 1000 to $1100 \mathrm{~kg}$ of available dry matter per hectare (ADM) left after grazing. As a result of average pasture growth rates in late April and May of about $35 \mathrm{~kg} \mathrm{DM} / \mathrm{ha} /$ day, this increases to approximately $2500 \mathrm{~kg} \mathrm{ADM} / \mathrm{ha}$ about 6 weeks later. At this stage pasture can be used as the sole diet for cows which by now have been dried off. The condition of the cows, which are in the weight range of 340 to $360 \mathrm{~kg}$, and 2 to 3 months from calving, can be maintained for about 3 weeks by grazing them at the rate of 550 to $600 /$ ha/day, each cow consuming -3.6 to $4.1 \mathrm{~kg} \mathrm{DM} /$ day. Under this stocking rate each grazing removes about $80 \%$ of the ADM, leaving a residue of about $500 \mathrm{~kg} \mathrm{ADM} / \mathrm{ha}$. From then until calving, intakes must be raised to allow for the rapid growth of the foetus, especially during the last month of pregnancy when the daily feed DM consumed by each cow should be 1.4 to $1.5 \%$ of liveweight about 5.5 to $6.0 \mathrm{~kg} \mathrm{DM} / \mathrm{cow} /$ day.

A feeding regime at this stage which results in daily weight gains of 0.7 to $0.9 \mathrm{~kg}$ (slightly greater than foetal weight gain) 
is associated with a $20 \%$ increase in milk production over the first 2 months of lactation, compared with the output from cows which only maintain weight before calving (Hutton, 1968, 1972; Hutton and Parker, 1973). To achieve these gains on pastures which during June-July have been growing at an average rate of about $22 \mathrm{~kg} \mathrm{DM} / \mathrm{ha} / \mathrm{day}$, and at the time of grazing then have only approximately $1800 \mathrm{~kg} \mathrm{ADM} / \mathrm{ha}$ on them, stocking rates 'must be reduced progressively to $250-270$ cows/ha/day and the utilization of $\mathrm{ADM}$ consequently will fall to about $70 \%$, again leaving an ungrazable residue of about $500 \mathrm{~kg}$ ADM/ha. Thus, as pregnancy advances, the area grazed increases markedly and pasture utilization is reduced slightly, so that under high stocking rates most of the farm has to be used for wintering the herd.

This can increase the risks of making costly errors in feeding and management. Hence, farmers and advisers need to be aware of practical guidelines for estimating the availability and quality of feed, and the requirements of cattle, and need to use these right through the year, but especially from late autumn through to spring.

\section{GUIDELINES}

\section{Pasture Quality}

Pasture quality is constantly changing, but is generally similar for the same season in different years. Quality is also reasonably predictable for the most common supplements, hay and silage. On a dry matter basis: $1 \mathrm{~kg}$ of winter-spring pasture is equivalent to about $1 \frac{1 / 2}{\mathrm{~kg}}$ of hay and $1 \frac{1 / 4}{\mathrm{~kg}}$ of grass silage.

\section{Feed Requirements}

Compared with her average needs before calving, 2 cow's feed requirement trebles in early lactation, Thus, without considerable grass reserves or supplements it is virtually impossible for cows which calve in July to express their full productive potential, even at stocking rates $2 \mathrm{~s}$ low as 2.5 cows plus replacements per hectare, since daily pasture growth per hectare at that stage is insufficient to support 2.5 milking cows.

\section{Amounts of FEed Avatlable}

ADM is not unduly difficult to assess once experience has been gained in subjective methods of appraisal of amounts of pasture cover by eye. In one experiment reported by Hutton and Parker 
(1973), and in more recent short-term ones (Hutton, unpublished data; T. F. Reardon, pers. comm.), daily subjective assessments of pasture availability, both before and after grazing, were compared with measurements made by cutting, drying and weighing samples from plots representative of the grazing areas. Correlation coefficients of 0.82 indicated that a very high proportion of the variation in DM between plots was accounted for by visual assessment, indicating that the latter can be used with considerable confidence. Experience gained in the use of this technique imparts the confidence to make the management changes required to raise the efficiency of farms through increased stock numbers without impairing individual animal performance.

In all the experimental work so far cited, as well as that described by Bryant and Parker $(1970,1971)$ and Bryant et al. (1971), one particularly valuable practice was employed consistently. Throughout each year feed supplies in all paddocks were assessed and recorded each week. This provided a continuous commentary on the feed situation so that positive control could be exercised over the herd intake, and hence on each season's production. This practice provided a rational basis for making such management decisions as paddock grazing order, the particular paddocks to be withdrawn for conservation, and the timing and extent of this. It provided also advanced warning of probable needs for supplementary feeding, gave increased flexibility and control to management and, most importantly, it minimized waste of feed.

\section{CONCLUSION S}

Various types and descriptions of feed budgets have been published recently by farm advisers in most of the national farming journals, the farming pages of newspapers and advisory leaflets. It is not intended that this paper should provide another example, but rather that it should emphasize some of the factors and important principles involved in feed budgeting, since knowledge of these facilitates preparation and intelligent application of such programmes.

On a herd basis perfect integration of animal needs with available feed is rarely achieved. Nevertheless, with the methods outlined, consistent improvements can be made in winter feeding practices. To achieve these, farmers must be continuously aware of the total quantities of feed they have available, the manner and rate at which these are changing, and how these quantities can be used most effectively in both the short and long term. 
In making such assessments and projections, farmers inevitably become more conscious of the capabilities of both their pastures and their stock. In turn, this knowledge develops the necessary confidence to raise carrying capacities and farming efficiency further.

Although the examples considered have been derived specifically from dairying, methods discussed have application equally to beef cattle and sheep production, and probably will be of even greater significance in areas where pasture growth is less predictable than in South Auckland.

\section{ACKNOWLEDGEMENTS}

Grateful thanks to Dr J. B. Hutton for critical encouragement and assistance, and to P. E. Donnelly for advice.

\section{REFERENCES}

Anon., 1971: N.Z. Dairy Board,

Production Report: 26, 73, 81.

Bryant, A. M.; Parker, 0. F., 1970: Proceedings of the R uakura Farmers' Conference W eek: 123-136. 1971: ibid., 110-120.

Bryant, A. M.; Parker, 0. F.; Cook, M. A. S.; Taylor, M. J., 1971: Proceedings of the N.Z. Grassland Association Conference, 33: 83-9.

Hutton, J. B., 1962: Proceedings of fhe Ruakura Farmers' Conference Week: $156-171$.

1963: ibid.: 194-208.

1966a: N.Z. Agricultural Science, 1 (4): 18-23. $168-80$.

1966b: Proceedings of the Ruakura Farmers' Conference W eek:

1968: ibid.: 215-27.

1971: ibid.: 195 (Abstract).

1972: ibid.: (In press).

Hutton, J. B.; Parker, O. F., 1973: N.Z. Journal of A gricultural Research, 16: $95-104$

Joyce, J. P.; MacLean, K. S., 1970: Proceedings of the R uakura. Farmers' Conference Week: $15-25$.

Wallace, L. R., 1958: Proceedings of the Ruakura Farmers' Conference Week: $216-27$. 